\title{
The Concept of Employability
}

\author{
Ronald W. McQuaid and Colin Lindsay
}

[Paper first received, March 2004; in final form, June 2004]

Summary. The concept of 'employability' plays a crucial role in informing labour market policy in the UK, the EU and beyond. This paper analyses current and previous applications of the term and discusses its value as an exploratory concept and a framework for policy analysis. It then traces the development of the concept, discusses its role in current labour market and training strategies (with particular reference to the UK) and seeks to identify an approach to defining employability that can better inform labour market policy, by transcending explanations of employment and unemployment that focus solely on either supply-side or demand-side factors. Although the literature offers a range of definitions of 'employability', many policy-makers have recently used the term as shorthand for 'the individual's employability skills and attributes'. It is argued that this 'narrow' usage can lead to a 'hollowing out' of the concept of employability. The paper concludes by presenting a broad framework for analysing employability built around individual factors, personal circumstances and external factors, which acknowledges the importance of both supply- and demand-side factors.

\section{Introduction}

'Employability' plays a crucial role in informing labour market policy in the UK, the EU and beyond. The concept of employability has been deployed to describe the objectives of the economic strategies promoted by important supranational institutions and labour market policies at national, regional and local levels (see for example OECD, 1998; CEC, 1999; ILO, 2000; UN, 2001). In the UK, employability has emerged as a central tenet of so-called 'Third Way' policies: 'a cornerstone of the New Labour approach to economic and social policy' (Haughton et al., 2000, p. 671). Despite, or perhaps because of, its ubiquity, the concept of employability continues to be used in a number of contexts and with reference to a range of meanings (Hillage and Pollard, 1998; McQuaid and Lindsay, 2002). Indeed, for some, employability is little more than a 'buzzword' that is more often used than properly understood (Philpott, 1999); or "a fuzzy notion, often ill-defined and sometimes not defined at all" (Gazier, 1998a, p. 298).

This paper seeks to contribute to the debate surrounding employability, by analysing current and previous applications of the term and discussing its potential value as an exploratory concept and a framework for policy analysis. The aims of the paper are therefore: to trace the development of the concept; to discuss its role in informing current labour market and training policies (with particular reference to the UK); and to identify an approach to defining the concept that can better inform labour market policy, by transcending explanations 
of unemployment that focus solely on either supply- or demand-side factors.

Following this introduction, section 2 of the paper discusses the importance of the concept of employability to local, national and international labour market policy. Section 3 considers working definitions of employability and traces the historical development of the concept. Section 4 examines in detail the manner in which the concept is currently applied in discussions of labour market policy in the UK. In section 5 of the paper, we argue that the manner in which the term 'employability' is currently used by many policy-makers, as shorthand for 'the individual's employability skills', represents a 'narrow' usage of the concept and contrast this with attempts to arrive at a more broadly defined concept of employability. In section 6, an holistic framework for understanding employability is set out, acknowledging the importance of both supply-side and demand-side factors affecting the labour market outcomes experienced by individuals. Finally, some conclusions are presented. The concept of employability relates to those: in work and seeking to improve or sustain their position in the labour market; in education; and out of work. However, the focus of this paper is largely, but not exclusively, on employability as it relates to unemployed job seekers and labour market policy.

\section{Employability and Labour Market Policy}

Employability, a relatively obscure concept a decade ago, now commands a central place in labour market policies in the UK, many other European states and beyond. At the supranational level, employability formed one of the four original pillars of the European Employment Strategy, having emerged as a defining theme of the Extraordinary European Council on Employment (the so-called Jobs Summit), which took place in Luxembourg in November 1997 (CEC, 1999). The promotion of employability in the workplace and among young people, the unemployed and other potentially disadvantaged groups in the labour market remains an important goal for the revised European Employment Strategy, formulated in 2003, which emphasises three overarching objectives: full employment; quality and productivity at work; and cohesion and an inclusive labour market (CEC, 2003a).

Whereas the original EU strategy included employability as a pillar of its approach, the more flexible, longer-term strategy now advocated by the European Commission speaks of promoting more and better 'investment in human capital and strategies for lifelong learning'. However, this and many of the Commission's other guidelines for implementing the strategy (or so-called ten commandments) reflect the pre-existing focus on employability, including: the promotion of active and preventative measures for the (especially long-term) unemployed and inactive; improving financial incentives to make work pay; and promoting active ageing (CEC, 2003b).

Other cross-national institutions concerned with labour market policy have similarly emphasised the importance of employability. The United Nations (UN) has made employability one of its four priorities for national policy action on youth employment (along with entrepreneurship, equal opportunities between young men and women and employment creation). To this end, the UN's Youth Employment Network has suggested that

All countries need to review, re-think and re-orient their education, vocational training and labour market policies to facilitate the school to work transition and to give young people ... a head start in working life (UN, 2001, p. 4).

Finally, the OECD's influence in promoting employability-focused labour market policies arguably pre-dates both of these initiatives. Although less inclined to deploy the concept of 'employability', by the mid 1990s the OECD (1994a, 1994b) had begun to advocate strongly more active labour market policies in order to break the 'dysfunctional division' between the working population and the unemployed. The need for strategies targeting "low-paid and unskilled job seekers [and] 
enhancing the effectiveness of active labour market policies and lifelong learning to maintain employability" continued to form the central focus of the Organisation's labour market policy agenda throughout the 1990s (OECD, 1998, p. 4). Indeed, it has been argued that by the end of the decade the OECD (particularly through its 1994 'Jobs Study') had played a crucial role in promoting active policies to improve the employability of the unemployed across international boundaries (Sinfield, 2001).

At the national level in the UK, as in many other EU states, the European Employment Strategy's focus on employability (and especially on providing a 'fresh start' to the young unemployed who have been out of work for at least six months) has been particularly influential. Employability was a key theme of UK's EU presidency in 1998 (Verhaar and Smulders, 1999). The concept has found expression within the UK's national Employment Action Plans and the current government's welfare to work agenda, with the New Deal programmes at its centre (DfEE, 1997a, 1997b, 1998; DWP, 2002). Improving the employability of young people, the long-term unemployed, lone parents, the disabled and other disadvantaged job seekers is the primary objective for the New Deal, which seeks to provide interventions designed to address the skills of participants while also 're-attaching' them to the labour market. Indeed, ministers have described the New Deal as being defined by the principles of 'quality, continuity and employability' (DfEE, 1997a). At regional and local levels, many of these, or similar, policies to tackle employability issues have been implemented or devised by area-based development agencies, local authorities and other bodies such as careers services.

This discussion illustrates that employability is not merely a subject of theoretical debate. The concept has become a cornerstone of labour market policies and employment strategies in the UK and elsewhere. Yet it is perhaps only the relatively recent emergence of employability as an all-embracing objective for national and supranational policies to address unemployment that has led to attempts to arrive at a thoroughgoing definition. Prior to discussing a broad concept of employability, however, we will review some established definitions and current and historical uses of the term.

\section{What Is Employability?}

\subsection{Working Definitions}

As noted above, the concept of employability continues to be applied within a range of different contexts and to both those in work and those seeking work. Accordingly, while it is simple enough to assign 'employability' a straightforward dictionary definition, such as 'the character or quality of being employable', arriving at a working definition is a far more complex process. Perhaps understandably, employers have tended to view employability as primarily a characteristic of the individual. The Confederation of British Industry (CBI) has defined employability thus

Employability is the possession by an individual of the qualities and competencies required to meet the changing needs of employers and customers and thereby help to realise his or her aspirations and potential in work (CBI, 1999, p. 1).

The UK government has similarly arrived at a definition that, while implying that employability-development is a priority for government, again places individuals' skills at the centre of the concept

Employability means the development of skills and adaptable workforces in which all those capable of work are encouraged to develop the skills, knowledge, technology and adaptability to enable them to enter and remain in employment throughout their working lives (HM Treasury, 1997, p. 1).

Other attempts to define the concept have hinted at a more holistic approach, emphasising the impact of both individual characteristics and labour market conditions-i.e. both labour demand and supply factors. The Canadian government's Labour Force 
Development Board offered the following definition

Employability is the relative capacity of an individual to achieve meaningful employment given the interaction of personal circumstances and the labour market (Canadian Labour Force Development Board, 1994, p. viii).

Similarly, research for the Northern Ireland Executive has explicitly suggested a wide working definition of employability

Employability is the capability to move into and within labour markets and to realise potential through sustainable and accessible employment. For the individual, employability depends on: the knowledge and skills they possess, and their attitudes; the way personal attributes are presented in the labour market; the environmental and social context within which work is sought; and the economic context within which work is sought (DHFETE, 2002, p. 7).

The Northern Irish approach appears to follow on from approaches such as that suggested by Hillage and Pollard (1998) who developed a broad-ranging definition of the concept, seeing employability as an individual's ability to gain initial employment, maintain employment, move between roles within the same organisation, obtain new employment if required and (ideally) secure suitable and sufficiently fulfilling work. Hence this covers both unemployed people looking for work and employed people seeking alternative jobs or promotion. Employability thus involves

The capability to move self-sufficiently within the labour market to realise potential through sustainable employment. For the individual, employability depends on the knowledge, skills and attitudes they possess, the way they use those assets and present them to employers and the context (e.g. personal circumstances and labour market environment) within which they seek work (Hillage and Pollard, 1998, p. 12).
In general, the differences in perspectives appear to revolve fundamentally around whether the focus is upon the individual's characteristics and 'readiness' for work, or upon the factors influencing a person getting into a job (or job 'match' in job search theory), moving jobs or improving their job.

\subsection{The Historical Evolution of the Concept of Employability}

The historical antecedents of the current employability debate can be traced back at least a century. Gazier's (1998a, 1998b, 2001) work on employability provides a useful overview of the concept's development towards currently accepted definitions. He distinguishes between seven operational versions of the concept of employability—namely

- Dichotomic employability-emerging at the beginning of the 20th century in the UK and the US. Gazier describes this formulation of the concept of employability as 'dichotomic' due to its focus on the opposite poles of 'employable' and 'unemployable', initially with little or no gradation: employable referring to those who were able and willing to work; unemployable referring to those unable to work and in need of 'relief'.

-Socio-medical employability-emerging before the $1950 \mathrm{~s}$ in the US, the UK, Germany and elsewhere, referring to the distance between the existing work abilities of socially, physically or mentally disadvantaged people and the work requirements of employment.

- Manpower policy employability-developed mainly in the US since the 1960s, and extending underlying discussions of socio-medical employability to other socially disadvantaged groups, with the emphasis again on the distance between the existing work abilities of the disadvantaged and the work requirements of employment.

- Flow employability - emerging in the French sociology literature of the 1960s, and focusing on the demand side and the accessibility of employment within local and national economies, with employability defined as 
"the objective expectation, or more or less high probability, that a person looking for a job can have of finding one" (Ledrut, 1966; quoted in Gazier, 1998b, p. 44).

- Labour market performance employability-used internationally since the end of the 1970s. This understanding of the concept focuses on the labour market outcomes achieved by policy interventions, measurable in terms of days employed, hours worked and payment rates, and other labour market outcomes for individuals participating in employability-related programmes.

- Initiative employability-emerging in the North American and European human resource development (HRD) literature of the late 1980s, reflecting an acceptance amongst individuals and organisations that successful career development requires the development of skills that are transferable and the flexibility to move between job roles. Again, the focus is on the individual, with the onus on workers to develop their skills and networks in the workplace, so strengthening their position when they wish, or are required, to move.

- Interactive employability-emerging first in North America and then internationally since the end of the 1980s, and maintaining the emphasis on individual initiative, while also acknowledging that the employability of the individual is relative to the employability of others and the opportunities, institutions and rules that govern the labour market. This can be seen as implying the importance of the role of employers and labour demand in determining a person's employability. Gazier identifies two main operational implications arising from this approach to employability: the targeting of long-term unemployed people and other disadvantaged groups by policy-makers; and the resulting focus of many Western governments on activation policies which seek to intervene to prevent long-term unemployment and labour market disadvantage.

Gazier suggests that these seven versions of the concept of employability can be identified as emerging in three waves. The first wave, and the first use of the concept, centring on 'dichotomic employability', emerged in the early decades of the 20th century. Although useful for distinguishing the 'employable' from the 'unemployable' (i.e. those eligible for welfare benefits), this rather simplistic version of the concept was more an 'emergency distinction' than a labour market policy tool. However, a version of this concept has been raised more recently in labour market models concerning whether unemployed people may be 'unemployable', partly due to technological change (SaintPaul, 1996). The second wave began around the 1960 s, as three very different versions of the concept were used by statisticians, social workers and labour market policy-makers. 'Socio-medical employability' and the related 'manpower policy employability' focused on identifying and measuring the distance between individual characteristics and the demands of work in the labour market. 'Flow employability', limited almost entirely to the French policy literature, offered a radical alternative, focusing on the demand side of the labour market, macro-level economic change and (crucially) the absorption rate of the economy.

Gazier acknowledges that these versions of employability have now largely given way to a third wave incorporating three new formulations of the concept, originating in the 1980s and developed in the 1990s: the outcome-based 'labour market performance employability'; 'initiative employability', with its focus on individual responsibility; and 'interactive employability', which "maintains the focus on individual adaptation, but introduces a collective/interactive priority" (Gazier 1998a, p. 300). Gazier concludes that while earlier versions of the concept of employability have fallen away, having been exposed as too static and one-sided, 'labour market performance employability' remains a basic component of policy evaluation (although, notably, it is not explicitly attached to any more general view of employability), while 'initiative employability' has retained a limited role in HRD thinking. 
Indeed, human resource development literature has continued to use employability as an important explanatory and descriptive concept, with employer-employee relations no longer being seen as being based on the traditional model of reciprocal loyalty (Rajan, 1997; Ellig, 1998; Baruch, 2001). Instead, they involve a form of personal, psychological contract from which the individual seeks: a sense of balance between personal time and work; a form of work organisation that allows autonomy to concentrate on specifically defined objectives; and, personal development made possible through continuous learning that adds to individual employability. From a business perspective, the promotion of employability both within and beyond the organisation has therefore become increasingly viewed as the key to developing a 'flexible and adaptable' workforce (CBI, 1999). Similarly, the UK government has recognised that an individual's employment security increasingly depends not upon attachment to a single employer, but on their having skills that will attract a range of employers (DfEE, 1997c).

Finally, Gazier suggests that a consensus has gradually emerged around the concept of 'interactive employability' as a defining idea in labour market policy, reflecting an acceptance that employability is about overcoming a broad array of barriers to work faced by individuals and that employability policies should therefore focus not just on individuals. However, as we argue below, there is evidence that the current application of the concept of employability, at least within labour market policy, often, but not exclusively, leans heavily upon its individualcentred, supply-side components.

\section{The Rise of the Concept of Employability}

We have seen that the concept of employability has been used in various contexts and formats over a century. In the past decade or so, factors that have given increased impetus to the use of the concept of employability have included: its potential role in tackling the social inclusion of disadvantaged groups; a reaction to the consequences of high levels of the long-term unemployed and inactivity; and the trend towards new types of relationships between employers and employees. First, the increasing importance of employability in labour market policy can be partly sourced to an "emphasis on skillsbased solutions to economic competition and work-based solutions to social deprivation" (Hillage and Pollard, 1998, p. 4). Within this context, the drive for employability is more than a means of offering workers the opportunity to develop flexible skills as an alternative to security of tenure. Rather, the development of individuals' employability is viewed as a crucial step towards improving access to employment (particularly for disadvantaged groups) and therefore a necessary element within strategies seeking to address unemployment and social exclusion.

However, the emphasis on the skills of individuals implicit within much of the labour market policy literature has raised concerns that the 'interactive' elements of the concept of employability have been lost amongst a welter of discussions centring on how best to activate and 'up-skill' the unemployed and other disadvantaged groups. While Gazier (2001) and others suggest that employability is now commonly understood as involving an interaction between the individual and other actors and conditions in the labour market, the policy debate and the content of labour market strategies have often focused on individual-centred, supply-side solutions. This supply-side policy orthodoxy has antecedents in both economic and social theory, related to responses to economic instability and labour market change, and attempts to re-establish the balance between the rights and responsibilities of individuals within Western welfare states. These issues are discussed below, with particular reference to UK labour market policy (although, as noted above, they are of similar importance within the EU and international policy context). However, most local strategies (as opposed to specific policies within them) appear to 
consider both demand and supply factors, although the two may not necessarily be well integrated.

There is little doubt that structural shifts have created mismatches between labour supply and demand-in sectoral terms, there has been a shift in the UK, as elsewhere, towards various service industries. This has resulted in changing skills needs (with 'soft skills', such as interpersonal and communication skills increasingly valued (see, for example, Belt and Richardson, 2005), but also a shift towards part-time and more flexible work practices. In occupational terms, there has been a shift towards non-manual work in general and knowledge work (requiring higher level skills and qualifications) in particular. Those without the skills to adapt to these changes are often faced with the choice of long-term unemployment or low-paid, unstable work. That the policy response to these problems has focused on the individual aspects of employability and has particularly targeted the long-term unemployed, reflects: first, a belief that measures to 'up-skill' and activate unemployed people will have positive impacts in terms of labour market participation, economic competitiveness and productivity; and, secondly, that long-term unemployment specifically is a crucial barrier to increased participation in the economy and wider society, and so to the realisation of these associated macro-economic benefits.

The UK government has explicitly identified concerns over structural unemployment and the impact of poor basic skills attainment on national productivity as informing its employability policy agenda (DWP, 2002). Although delivering 'employment opportunity for all' is seen by government ministers as an important element in social inclusion and poverty reduction, this egalitarian aspect of the employability agenda is consistently linked to broader economic concerns, including improved productivity and the control of wage inflation. As the then Secretary of State for Education and Employment noted

The employability agenda is about changing the culture-helping people to gain skills and qualifications they need to work in a flexible labour market ... If we can increase the numbers in work and improve the chances of work for the most disadvantaged, then more vacancies will turn into jobs rather than bottlenecks, skills shortages and inflationary pressures (Blunkett, 1999).

Thus, it has been argued that the Labour Party replaced its 'historic' commitment to full employment with a promise of 'full employability' (Finn, 2000)—equality of outcome is less the objective than equality of opportunity (Lister, 2001). The objective of the employability agenda as formulated here is the creation of a higher-skilled labour force and a more inclusive and competitive active labour market, leading to the combined benefits of social inclusion on the one hand, and downward pressures on wage inflation and improved productivity and competitiveness on the other. Philpott $(1998,1999)$ suggests that this inevitably leads to a two-part approach to employability policy — one focusing on activation and labour market attachment (or what Philpott calls 'access') and the other focusing on 'up-skilling' the labour force through employability training and lifelong learning (or 'performance ability').

As suggested above, a crucial element informing labour market policy in the UK refers to the particular importance attached to tackling long-term unemployment. Labour market economists have successfully argued that duration dependency - the increased likelihood of continued unemployment amongst the long-term jobless due to the deterioration of skills, work habits and commitment over time-has a major role to play in explaining high levels of structural unemployment (Blanchard and Summers, 1987; Layard et al., 1991; Layard, 1997; Abbring et al., 2001). This 'withering flowers' argument leads to the logical conclusion that effective active labour market programmes, aimed at activating and improving the skills of the longterm unemployed, have the potential both to impact positively on the employability of individual clients and permanently to ratchet 
down the rate of unemployment in the wider economy.

A second major strand of thinking informing current policies on employability (in the UK and elsewhere) reflects both a reaction to the social consequences of high levels of long-term unemployment, concern at increasing inactivity rates and an attempt to curtail rising social expenditure directed towards welfare recipients of working age. It is argued that policies to enhance the employability of unemployed groups (using a combination of 'access' and 'performance ability' measures) are required in order to re-establish the balance between the right to financial support through the social security system and the responsibilities of unemployed welfare claimants.

The theoretical bases for this approach have been cited as, amongst others: the 'underclass' thesis popularised by social theorists during the 1980s and 1990s (see for example Murray, 1990); and the alternative visions of central European Christian Socialism and social communitarianism (see for example Etzoni, 1993). What is clear is that, as with the duration dependency thesis in economic policy, there is a renewed acceptance in social policy circles that responses to unemployment must focus on the attributes and responsibilities of the individual. Indeed, with the introduction of major active labour market policies such as the New Deal, the UK has seen a shift towards 'a work-focused welfare state' (Evans, 2001) where labour market participation is arguably viewed as the ultimate solution to social and economic exclusion (Powell, 2000). The objective of the government is to provide 'work for those who can and security for those who cannot', by 'rebuilding the welfare state around work' (DSS, 1998). From the government's perspective, 'work is the best form of welfare' (DfEE, 2001) and "the best antipoverty, anti-crime and pro-family policy yet invented" (Labour Party, 2001, p. 24).

The recent development of employabilityfocused welfare to work policies in response to this agenda has been supported by those who argue that client-centred training programmes, even if compulsory, mark a considerable advance on the approach of government policy during the 1980s and early 1990s, which included using benefit cuts and an increasingly stringent job-seeking regime in an attempt to force unemployed people to enter low-paid work (White, 2000; Lindsay, 2001). Furthermore, the development of policies designed to 'make work pay', such as the 2003 Child Tax Credit and Working Tax Credit reforms, arguably represent an acknowledgement by government of the need for additional financial support for those making the transition from welfare to work (Bryson, 2003).

Nevertheless, there remain considerable concerns regarding the employability agenda as currently formulated within labour market policy in the UK and elsewhere. Peck and Theodore (2000, p. 729) suggest that, while the concept of employability may seem relatively new, "the kind of supply side fundamentalism that it signifies most certainly is not". Similarly, Serrano Pascual (2001a, 2001b) argues that the concept of employability, as understood within the European Employment Strategy and national welfare to work policies, evokes a 'traditional' reactionary understanding of unemployment, which seeks to blame the jobless individual's predicament upon his or her inadequacies, rather than acknowledging a lack of opportunity within the labour market.

The supply-side orthodoxy that informs most current approaches to employability policies at the UK and EU levels has been challenged by those who question the extent to which labour market inclusion and social inclusion can be equated. Cook et al. (2001) argue that the preponderance of low-paid, casualised work within the UK economy means that work-first approaches have the potential to accentuate rather than mitigate the social exclusion. There is also evidence that current supply-side initiatives have not been effective in addressing the needs of people with multiple or severe disadvantages (Millar, 2000). Clearly, 'one size fits all' employability programmes which emphasise a work-first, labour market attachment 
approach cannot be expected to assist all people facing severe health, personal or social problems that require interventions that are personalised, intensive, flexible and (if necessary) long-term (Lakey et al., 2001). It has also been argued that the situation of these individuals is not assisted by "the corrosive effects of an ideological ethos that encourages people with multiple needs and problems to blame themselves for their failure in the labour market" (Dean et al., 2003, p. 24).

The assumptions underlying the current employability policy agenda have faced further challenges, questioning the extent to which the 'long-term unemployment problem' is independent of general levels of unemployment with the economy (Machin and Manning, 1999; Webster, 2000) and the need to address problems of demand in local labour markets. From this perspective, welfare to work initiatives which focus on improving the individual aspects of employability fail to acknowledge the strong link between weak labour demand and high 'welfare usage' in disadvantaged communities (Peck, 2001). The 'jobs gap' in many of Britain's cities (in a large part a result of the restructuring of manufacturing industries) has meant that employability-focused programmes have encountered far larger client groups in these areas and have predictably struggled to match the results achieved in more affluent, 'job-rich' areas (Turok and Edge, 1999; Martin et al., 2003). In more general terms, labour market analysts have argued that a purely supply-side focus fails to acknowledge the impact of employers' attitudes and the nature of contracts and conditions (such as shift patterns, wages, location) on the ability of job seekers to pursue certain opportunities (Adams et al., 2000, 2002).

What Gazier (1998b, 2001) describes as the 'interactive' formulation of the concept of employability has in reality been adapted by policy-makers and labour economists to become a buzzword for supply-side labour market strategies (Peck and Theodore, 2000). The focus is indeed on the interaction of the individual with the labour market, but the 'problem' is often seen as resting with the individual. Accordingly, 'so-called' employability policies have too often focused solely on activating the unemployed through a combination of compulsory training and job-seeking activities. That the success of these policies tends to differ significantly across regions and labour markets points to a fundamental weakness - that the concept of employability as currently formulated within many activation policies fails to acknowledge the importance of the geography of labour markets, issues surrounding travel to work, employer attitudes and behaviour, demand within local economies and other 'context' factors impacting on the experiences of job seekers.

\section{Supply-side and Broader Concepts of Employability}

\subsection{Employability and the 'Supply-side Orthodoxy'}

It might therefore be argued that the concept of employability-particularly as applied within many supply-side labour market policies-has been 'hollowed out' in many current theoretical and policy discussions. In many cases, the interactivity supposedly at the centre of the concept appears to have been replaced by a singular focus on the individual and what might be termed their 'employability skills'. The employability skills or individual assets possessed by workers and job seekers, and the extent to which these tie in with the immediate needs of employers, have come to define many policy-makers' identification of skills gaps and understanding of the concept of employability. Lister (2001) characterises the current government's approach as concerned with the supply side of 'employability' rather than the demand side of 'employment'. Similarly, for Haughton et al.

[The current government's] rendering of the employability agenda taps into the orthodox strain of economic thinking which has it that both the underlying causes of, and the 
appropriate remedies to, unemployment essentially lie on the supply-side of the labour market; that the unemployed should be induced to price themselves back into work; that the government has neither the responsibility nor the capability to create jobs, but instead should direct its energies to the supply-side of the labour market (Haughton et al., 2000, p. 670).

In local labour markets, the issues associated with labour demand are generally significant (both in terms of the opportunities that exist and the competition for jobs). Peck and Theodore argue that

employability-based approaches, which locate both the problems and the solutions in labour market policy on the supply-side of the economy, are not sufficient to the task of tackling unemployment, social exclusion and economic inequality (Peck and Theodore, 2000, p. 731).

As the previous discussion illustrates, the concept of employability pre-dates current definitions linked to neo-liberal and/or 'Third Way' labour market policies. What is important is the substance of the concept, and if employability is fundamentally about 'the character or quality of being employable' then there clearly must be a role for individual characteristics, personal circumstances, labour market and other external factors in explanations of the responses of employed or unemployed people to potential employment opportunities.

Many researchers who have sought to use the concept of employability as a means of analysing barriers to work amongst the unemployed have themselves stressed the need to avoid an approach that involves 'blaming the victim', or policies that offer solely supplyside solutions (see Hillage and Pollard, 1998; Kleinman et al., 1998; Evans et al., 1999). Kleinman and West (1998) accept that attempts to address employability with reference to supply-side measures alone risk being 'swamped' by rising levels of general unemployment in times of economic recession. The 'lack of employability' is thus viewed as a complex problem, rather than a simple failure with a simple remedy

It is the outcome of a complex of different factors, located in the labour market, in schools, in the recruitment procedures of businesses and in the economic policies implemented by government (Kleinman and West, 1998, p. 174).

The argument that long-term unemployed people face an 'employability gap' involving a complex combination of barriers to work has been used to advocate innovative supply-side solutions tailored to local labour demand (McQuaid and Lindsay, 2002) but also deployed to inform critiques of current, work-first labour market policies (Lindsay, 2002). Furthermore, the same analytical framework has been used to examine the barriers to work faced by job seekers in rural areas, with the effect of drawing attention to demand-side issues and problems of geographical remoteness (Lindsay et al., 2003). Employability, it is argued, should be understood as being derived from, and affected by, individual characteristics and circumstances and broader, external (social, institutional and economic) factors that influence a person's ability to get a job. The next section discusses a broad model of employability and the implications for policy.

\subsection{Broad Approaches to Employability}

Labour market and policy analysts concerned with arriving at an understanding of employability that is holistic, and so offers a realistic description of the factors affecting individuals' journeys in the labour market, have therefore sought to define the concept in a format that accounts for the full range of personal and external barriers impacting on the employability of workers and job seekers.

To take an example, a person may not be able to get or take a job due to: personal factors such as a lack of suitable skills; and/ or the lack of institutional infrastructure such as suitable childcare or transport in their area; and/or labour demand factors involving employer preferences (such as only shift 
work being available, or discrimination). Hence, each of these, and other, factors may have singly or jointly a profound impact on a person's employability-i.e. their ability to gain employment or move to a more suitable job. Such a broad approach to employability (of unemployed people or those in work) allows us to identify the real key interrelated barriers that actually prevent someone getting a new job, rather than merely identifying a subset, such as their 'employability skills' which may or may not be the actual main barrier. To elaborate one example, if employers in an area practise discrimination (based, for instance, on area of residence, gender, ethnicity or age), then a person who may have all the required employability skills and attributes will still not get employment if they belong to the discriminated group.

Given the increasing acceptance that discussions of employability cannot be limited to the orthodoxies of solely supply-side and demand-side economic theory, recent efforts to arrive at a clearer definition of the concept have emphasised the need to understand the interaction of individual and external factors affecting the individual's ability to operate effectively within the labour market. The focus of such analyses is on 'interactive' employability in its truest sense-the dynamic interaction of individual attributes, personal circumstances, labour market conditions and other 'context' factors.

To this end, Evans et al. (1999) suggest a division of employability into supply-side and demand-side elements (described as 'employability components' and 'external factors'). Employability components are identified as including

- the extent of the individual's transferable skills;

-the level of personal motivation to seek work;

-the extent of the individual's 'mobility' in seeking work;

- access to information and support networks;

- and the extent and nature of other personal barriers to work.

\section{External factors include}

- the attitudes of employers towards the unemployed;

- the supply and quality of training and education;

- the availability of other assistance for disadvantaged job seekers;

- the extent to which the tax-benefits system successfully eliminates benefit traps;

- and (most importantly) the supply of appropriate jobs in the local economy.

Similarly, Kleinman et al. (1998) discuss a range of 'micro' and 'macro' factors that define the detail of each side of the supplyside-demand-side equation. In an attempt to arrive at a definition of employability that would provide a 'framework for policy analysis' and a means of understanding the complexities of the barriers to work faced by individuals, Hillage and Pollard (1998) have drawn upon many themes from the existing literature. Their framework for employability seeks to highlight a complex interaction of different components, namely

-Employability assets: including baseline assets, such as basic skills and essential personal attributes (for example, reliability and honesty); intermediate assets, such as job-specific, generic and 'key' skills (e.g. communication and problem solving); and highlevel assets, such as those skills that contribute to organisational performance (for example, team work and commercial awareness).

- Presentation: defined as the ability to secure an appointment to an appropriate position through the demonstration of employability assets (for example, through the competent completion of a curriculum vitae or application form, or participation in an interview).

-Deployment: referring to a range of abilities including career management skills (for example, awareness of one's own abilities and limitations, awareness of opportunities in the labour market, and decision-making and transitional skills) and job-search skills.

- Context factors, or the interaction of personal circumstances and the labour market: Hillage and Pollard accept that the 
individual's ability to realise the assets and skills discussed above will to some extent depend upon external socioeconomic factors, personal circumstances and the relationship between the two. External conditions such as local labour market demand and employer attitudes will impact upon the availability of suitable opportunities, while personal circumstances will affect the ability of individuals to seek and benefit from opportunities.

The Hillage-Pollard employability framework, although perhaps the most thorough to date, hints at a continued emphasis on the supply side, at least in its organisation (Lindsay et al., 2003). Three of Hillage and Pollard's key components of employability (assets, deployment and presentation) operate at the individual level, while virtually everything outside the individual's immediate control is collapsed into a single category of 'context factors'. While there is clearly value in acknowledging that context does not merely refer to labour market conditions, but also involves a range of other external factors, there may be more effective ways of conceptualising and differentiating between personal circumstances and institutional, infrastructural and labour market barriers. The next section builds upon this to provide a broad employability framework.

\section{Towards a Broad Model of Employability}

Following from the above section, Table 1 illustrates our own re-ordered 'holistic' framework of employability. It has three main interrelated components, or sets of factors, that influence a person's employability: individual factors; personal circumstances; and external factors. The examples here and in Table 1 are not exhaustive. Some examples of policies related to each component are briefly discussed in this section. Of fundamental importance are the interactions between each of the components. For instance, employers may be willing to accept someone under one set of circumstances (for example, during a labour shortage), but may not consider the same individual to have the minimum necessary skills, etc. under different circumstances (for example, when there is a large supply of labour or when the firm does not have any pressing orders to fulfil). Even at a specific time and place, if demand changes (for example, an employer changes their childcare or job advertising policies) then this may result in new people seeking and getting employment with them. In this case, the individual has not changed their 'narrow' employability in terms of employability skills and attitudes, but their ability to take up work with the employer (and their 'broad' employability) has.

\subsection{Individual Factors}

The component covering 'Individual factors' involves, first, a person's 'employability skills and attributes'. Employability skills and attributes can be seen as broadly covering the overlapping: essential attributes (basic social skills, reliability, etc.); personal competencies (diligence, motivation, confidence, etc.); basic transferable skills (including literacy and numeracy); key transferable skills (problem-solving, communication, adaptability, work-process management, team-working skills); high-level transferable skills (including self-management, commercial awareness, possession of highly transferable skills); qualifications and educational attainment; work knowledge-base (including work experience and occupational skills); and labour market attachment (current unemployment/employment duration, work history, etc.).

These 'employability skills and attributes' cover many of the main aspects of the 'narrow' concept of employability. Also, there are some parallels between the categorisation of skills and attributes suggested here and human capital theory (see Becker, 1975) and wider discussions of skills acquisition and intelligence (see Gardner, 1999). ${ }^{1}$ These factors should not be considered as forming a hierarchy, as the nature and importance of different factors will change with circumstances and in many cases these factors 
Table 1. An employability framework (with examples)

\begin{tabular}{|c|c|c|}
\hline Individual factors & Personal circumstances & External factors \\
\hline $\begin{array}{l}\text { - Employability skills and } \\
\text { attributes } \\
\text { Essential attributes } \\
\text { Basic social skills; honesty } \\
\text { and integrity; basic personal } \\
\text { presentation; reliability; } \\
\text { willingness to work; } \\
\text { understanding of actions and } \\
\text { consequences; positive } \\
\text { attitude to work; } \\
\text { responsibility; self- } \\
\text { discipline } \\
\text { Personal competencies } \\
\text { Proactivity; diligence; self- } \\
\text { motivation; judgement; } \\
\text { initiative; assertiveness; } \\
\text { confidence; act } \\
\text { autonomously } \\
\text { Basic transferable skills } \\
\text { Prose and document literacy; } \\
\text { writing; numeracy; verbal } \\
\text { presentation } \\
\text { Key transferable skills } \\
\text { Reasoning; problem- } \\
\text { solving; adaptability; } \\
\text { work-process management; } \\
\text { team working; personal task } \\
\text { and time management; } \\
\text { functional mobility; basic } \\
\text { ICT skills; basic } \\
\text { interpersonal and } \\
\text { communication skills; } \\
\text { emotional and aesthetic } \\
\text { customer service skills } \\
\text { High level transferable skills } \\
\text { Team working; business } \\
\text { thinking; commercial } \\
\text { awareness; continuous } \\
\text { learning; vision; job-specific } \\
\text { skills; enterprise skills } \\
\text { Qualifications } \\
\text { Formal academic and } \\
\text { vocational qualifications; } \\
\text { job-specific qualifications } \\
\text { Work knowledge base } \\
\text { Work experience; general } \\
\text { work skills and personal } \\
\text { aptitudes; commonly valued } \\
\text { transferable skills (such as } \\
\text { driving); occupational } \\
\text { specific skills } \\
\text { Labour market attachment } \\
\text { Current unemployment/ } \\
\text { employment duration; }\end{array}$ & $\begin{array}{l}\text { - Household circumstances } \\
\text { Direct caring } \\
\text { responsibilities } \\
\text { Caring for children, elderly } \\
\text { relatives, etc. } \\
\text { Other family and caring } \\
\text { responsibilities } \\
\text { Financial commitments to } \\
\text { children or other family } \\
\text { members outside the } \\
\text { individual's household; } \\
\text { emotional and/or time } \\
\text { commitments to family } \\
\text { members or others } \\
\text { Other household } \\
\text { circumstances } \\
\text { The ability to access safe, } \\
\text { secure, affordable and } \\
\text { appropriate housing } \\
\text { Work culture } \\
\text { The existence of a culture in } \\
\text { which work is encouraged } \\
\text { and supported within the } \\
\text { family, among peers or other } \\
\text { personal relationships and } \\
\text { the wider community } \\
\text { - Access to resources } \\
\text { Access to transport } \\
\text { Access to own or readily } \\
\text { available private transport; } \\
\text { ability to walk appropriate } \\
\text { distances } \\
\text { Access to financial capital } \\
\text { Level of household income; } \\
\text { extent and duration of any } \\
\text { financial hardship; access to } \\
\text { formal and informal sources } \\
\text { of financial support; } \\
\text { management of income and } \\
\text { debt } \\
\text { Access to social capital } \\
\text { Access to personal and } \\
\text { family support networks; } \\
\text { access to formal and } \\
\text { informal community support } \\
\text { networks; number, range and } \\
\text { status of informal social } \\
\text { network contacts }\end{array}$ & $\begin{array}{l}\text { Demand factors } \\
\text { Labour market factors } \\
\text { Level of local and regional } \\
\text { or other demand; nature } \\
\text { and changes of local and } \\
\text { regional demand (required } \\
\text { skill levels; occupational } \\
\text { structure of vacancies; } \\
\text { sectors where demand is } \\
\text { concentrated); location, } \\
\text { centrality/remoteness of } \\
\text { local labour markets in } \\
\text { relation to centres of } \\
\text { industry/employment; level } \\
\text { of competition for jobs; } \\
\text { actions of employers' } \\
\text { competitors; changing } \\
\text { customer preferences, etc. } \\
\text { Macroeconomic factors } \\
\text { Macroeconomic stability; } \\
\text { medium- to long-term } \\
\text { business confidence; level } \\
\text { and nature of labour demand } \\
\text { within the national economy } \\
\text { Vacancy characteristics } \\
\text { Remuneration; conditions } \\
\text { of work; working hours and } \\
\text { prevalence of shift work; } \\
\text { opportunities for } \\
\text { progression; extent of } \\
\text { part-time, temporary and } \\
\text { casual work; availability } \\
\text { of 'entry-level' positions } \\
\text { Recruitment factors } \\
\text { Employers' formal } \\
\text { recruitment and selection } \\
\text { procedures; employers' } \\
\text { general selection preferences } \\
\text { (for example, for recent } \\
\text { experience); employers' } \\
\text { search channels (methods } \\
\text { of searching for staff when } \\
\text { recruiting); discrimination } \\
\text { (for example, on the basis } \\
\text { of age, gender, race, area } \\
\text { of residence, disability, } \\
\text { unemployment duration); } \\
\text { form and extent of } \\
\text { employers' use of informal } \\
\text { networks; demanding only } \\
\text { appropriate qualifications or } \\
\text { credentials }\end{array}$ \\
\hline
\end{tabular}


Table 1. Continued

\begin{tabular}{|c|c|c|}
\hline Individual factors & Personal circumstances & External factors \\
\hline $\begin{array}{l}\text { number and length of spells of } \\
\text { unemployment/inactivity; } \\
\text { 'balance' of work history } \\
\text { - Demographic characteristics } \\
\text { Age, gender, etc. } \\
\text { - Health and well-being } \\
\text { Health } \\
\text { Current physical health; } \\
\text { current mental health; medical } \\
\text { history; psychological well- } \\
\text { being } \\
\text { Disability } \\
\text { Nature and extent of: physical } \\
\text { disability; mental disability; } \\
\text { learning disability } \\
\text { Job seeking } \\
\text { Effective use of formal search } \\
\text { services/information resources } \\
\text { (including ICT); awareness } \\
\text { and effective use of informal } \\
\text { social networks; ability to } \\
\text { complete CVs/application } \\
\text { forms; interview skills/ } \\
\text { presentation; access to } \\
\text { references; awareness of } \\
\text { strengths and weaknesses; } \\
\text { awareness of location and type } \\
\text { of opportunities in the labour } \\
\text { market; realistic approach to } \\
\text { job targeting } \\
\text { Adaptability and mobility } \\
\text { Geographical mobility; wage } \\
\text { flexibility and reservation } \\
\text { wage; occupational flexibility } \\
\text { (working hours, occupations, } \\
\text { sectors) }\end{array}$ & & $\begin{array}{l}\text { Enabling support factors } \\
\text { Employment policy factors } \\
\text { Accessibility of public } \\
\text { services and job-matching } \\
\text { technology (such as job } \\
\text { search/counselling); } \\
\text { penetration of public } \\
\text { services (for example, use } \\
\text { and credibility among } \\
\text { employers/job seekers); } \\
\text { incentives within tax- } \\
\text { benefits system; existence of } \\
\text { 'welfare to work'/activation } \\
\text { and pressure to accept jobs; } \\
\text { accessibility and limitations } \\
\text { on training; extent of local/ } \\
\text { regional development } \\
\text { policies; measures to ease } \\
\text { the school-work transition } \\
\text { and address employability } \\
\text { issues at school and } \\
\text { university } \\
\text { Other enabling policy } \\
\text { factors } \\
\text { Accessibility and } \\
\text { affordability of public } \\
\text { transport, child care and } \\
\text { other support services }\end{array}$ \\
\hline
\end{tabular}

interact-for instance, a qualification such as a degree usually needs to be supplemented by transferable skills or social skills in order to gain employment (Holmes, 2001). Similarly, interpersonal, 'emotional' and 'aesthetic' skills are increasingly demanded by many employers, particularly where there is a direct interface with customers (Witz et al., 2003; Glomb and Tews, 2004). Enterprise skills (such as the ability to search systematically for and take opportunities, creativity, negotiating skills, etc.) have also emerged as of greater importance in recent years, as the adaptability of organisations, and their employees, has become more significant (see-for example, Drucker, 1985; Gibb, 1993; McQuaid, 2002; Hartshorn and Sear, 2005).

Recent employability-raising policies in the UK (with the New Deal at their centre) have adopted fairly 'standard' labour market approaches, based around training and basic skills assistance, although work placement and intermediate labour market programmes have gradually grown in importance (Finn, 2003; Fletcher, 2004). The emphasis here is on addressing basic gaps in the skills-sets and attributes listed above, while particularly 
emphasising labour market attachment. The targeting of these interventions on long-term unemployed people reflects the manner in which UK government policy has been informed by the argument that the duration structure of unemployment is the main determinant of the competitiveness of unemployed job seekers (see above, and Boeri et al., 2000; Robson, 2001).

'Demographic characteristics' include factors such as: age, gender, ethnicity etc. These may influence individuals' motivations or ability to carry out certain jobs.

'Health and well-being' factors include: health (physical and mental health, medical history, and physical ability to do different jobs, some of which may be age-related) and disability (including: the nature and extent of: physical disability; mental disability; learning disability). Within the UK policy context, dealing with long-term sickness among working-age men has become an important priority, although the extent to which rising levels of incapacity reflect deteriorating health, rather than 'hidden unemployment' remains a matter of debate (Nickell and Quintini, 2002). Policies such as the New Deal for Disabled People have sought to provide targeted job-matching support for those facing severe physical and other disabilities. While concerns have been raised regarding the policy's potential to force vulnerable groups into unsuitable work (Roulstone, 2000), there is also some evidence of positive outcomes for disabled participants who have been benefited from a return to work in environments providing 'supported employment' (Heenan, 2002).

'Job seeking' refers to how well a person identifies and searches for a job, including: the effective use of formal search services/ information resources; the use of appropriate technologies; awareness and effective use of informal social networks; ability to complete curriculum vitae and application forms, interview skills/presentation; labour market awareness including the appropriateness of the types of jobs sought; and the amount, efficiency and effectiveness of job-search effort. There is a considerable body of literature on job-search strategies, and the importance of which search channels are used, with what intensity and with what effectiveness (Holzer, 1988; Budd et al., 1998; Wanberg et al., 1999; Boheim and Taylor, 2001).

Job-search support is a major component of national employment policies (through Jobcentre Plus and Careers Service provision) and local policies, including ICT-based services (McQuaid et al., 2003). Again, the promotion of effective job seeking provides an important focus for national welfare to work programmes such as the New Deal. While the efficiency of formal services provided by state agencies has been questioned (Osberg, 1993), it has been demonstrated that the structured job-search assistance provided via the UK Jobcentre network can positively impact on job entry rates (Gregg and Wandsworth, 1996; Thomas, 1997). As with the other policy mechanisms discussed above, there remain concerns that a 'work first' approach will see job seekers pushed into work that cannot be sustained in the longer term (Daguerre, 2004). Nevertheless, the selection of effective job-search channels remains a key individual factor impacting on employability and therefore an appropriate priority for labour market policy (McQuaid et al., 2004).

Finally, 'adaptability and mobility' refers to: the job seeker's awareness of his or her own strengths and weaknesses; a realistic approach to job targeting; geographical mobility; wage flexibility and reservation wage; and occupational flexibility, including willingness to do shift work or flexible hours and to consider jobs across a range of sectors. There is a wealth of research pointing to the importance of wage flexibility to individuals' employability (see for example, Layard et al., 1994; Aberg, 2001; Bloeman and Stancanelli, 2001). However, there has been an increasing emphasis on broader measures of adaptability in the recent employability literature. In particular, the difficulties faced by older workers in adapting to the decline of 'traditional' sectors has been noted. Many older, male job seekers continue to look for work in these declining sectors (McQuaid and Lindsay, 2002) and are reluctant even to consider occupations in rapidly 
expanding areas of the service economy (Lindsay and McQuaid, 2004).

The adaptability of people to take up job offers or search more widely can be influenced by deterrent or 'push' policies. These seek to make life on benefits less attractive for the unemployed and encourage them to find work where it is available (Nickell, 1998; Layard, 2000). However, a number of alternative 'pull' mechanisms can also be deployed by government. In the UK, recent Tax Credit reforms and the establishment of a National Minimum Wage have enabled job seekers to demonstrate greater flexibility in their wage demands (McLaughlin et al., 2001; AdamSmith et al., 2003). Furthermore, while registered job seekers are required to demonstrate that they are 'actively seeking work' across a range of sectors, innovative local initiatives have been developed to assist older workers in the transition to work in unfamiliar sectors such as retail (Nickson et al., 2003).

\subsection{Personal Circumstances}

The second component, 'Personal circumstances', includes a range of socioeconomic contextual factors related to individuals' social and household circumstances. These may affect the ability, willingness or social pressure for someone to take up an employment opportunity. Household circumstances can be divided into: direct caring responsibilities (for example, for children or elderly relatives); other family and caring responsibilities (including financial commitments to children, emotional and/or time commitments to family members); and other household circumstances (such as the ability to access appropriate housing). An additional element of personal circumstances, 'work culture', refers to the wider social influences impacting on the individual's attitudes and aspirations, such as the existence of a culture in which work is encouraged and supported within the family, among peers and the wider community.

In terms of recent policy, the introduction of the Childcare Tax Credit in the UK marks a clear attempt to address the barriers to work faced by job seekers with caring responsibilities. The development of social housing policies in areas where home-ownership is unaffordable for many low-paid workers represents a similar attempt to respond to personal, household circumstances that can act as a barrier to work. More controversial is the continued emphasis in the current government statements on promoting a strong 'work culture' and challenging the perceived 'culture of worklessness' in some disadvantaged areas (DWP, 2003). The idea of an unemployed 'underclass' refusing work in favour of life on benefits was popular among some social theorists during the 1980s and 1990s (see above). However, the decline in unemployment among even the most disadvantaged groups as a result of sustained economic recovery after the mid 1990s in the UK and elsewhere undermined the argument that there is a large identifiable underclass (Freeman, 2000). Nevertheless, the targeting of additional job-search and training support on local authority wards with particularly high long-term unemployment (piloted from April 2004 in the UK as 'Working Neighbourhoods') may at least represent a concentration of resources in those local labour markets most in need of assistance.

Next, there are factors related to 'access to resources' including: transport/mobility issues (such as access private transport, ability to walk appropriate distances to work); access to financial capital (such as the level of household income and access to formal and informal sources of financial support); and access to social capital (such as personal and family support networks, formal and informal community support networks especially those relevant to job seeking). The latter concept-social capital-has become the focus of considerable interest in the jobsearch literature (Stoloff et al., 1999; Brown and Konrad, 2001; Chapple, 2002). In certain local economies (such as rural areas), social networks can be particularly important (Hofferth and Iceland, 1998; Monk et al., 1999). In more general terms, holding a large number of social ties (even if relatively weak) to higher-status workers has been shown to be associated with progression in 
the labour market (Granovetter, 1974, 1982) and, in some cases, exits from unemployment (Lévesque and White, 2001).

\subsection{External Factors}

Thirdly, 'External factors' include those influencing a person's employability, such as labour demand conditions and enabling support of employment-related public services. As discussed earlier, 'demand factors' include: local labour market factors (such as the level and nature of local and regional or other labour demand, location issues, centrality/remoteness of local labour markets in relation to centres of industry/employment, levels of competition for jobs); macroeconomic factors (macroeconomic stability, level and nature of labour demand within the national economy, etc.); vacancy characteristic factors (remuneration, conditions of work, working hours and prevalence of shift work, opportunities for progression, extent of part-time, temporary and casual work, availability of 'entry-level' positions if appropriate, etc.); and recruitment factors (including employers' formal recruitment and selection procedure and general selection preferences, employer discrimination, form and extent of employers' use of informal networks) (see Adams et al., 2000, for a wider discussion).

'Enabling support factors' for matching labour demand and supply include: employment policy factors (accessibility of public services and job-matching technologies, including information and communication technologies, information and job search/ counselling, use and credibility among employers and job seekers of public services, incentives within tax-benefits system, measures to ease the school-work transition); and other policy factors that help enable people to get a job (such as the accessibility and affordability of public transport or childcare). One example of local childcare support is the 'Working for Families' policy in Scotland which has a $£ 20$ million fund to help improve disadvantaged parents' employability through providing flexible childcare and other assistance to those moving from unemployment towards work.

Clearly, demand factors and enabling support factors are linked-labour market demand may be influenced by national policies concerning macro-economic growth and stability, anti-discrimination legislation and regional and local strategies to stimulate demand via support for inward investment and new firm development. Campbell (2000) also stresses the role that local labour market policies can have in reducing long-term unemployment. Similarly, many of these policy responses have been discussed above, highlighting the extent to which individual factors, personal circumstances and external (labour market and policy) factors are inherently linked. For example, the efficiency of individuals' job-search strategies can only be understood with reference to employers' recruitment preferences and channels. This relationship in turn operates within a set of specific labour market and policy contexts.

The framework discussed above shares similarities with those that have gone before. Perhaps its defining feature is the manner in which it seeks to clarify and acknowledge the status of individual factors, which can be addressed through standard supply-side policies targeted at job seekers, from personal circumstances that may require different policy interventions or may inherently limit individuals' labour market participation. Both of these groups of factors are in turn distinguished from employer-related, economic, institutional and labour market factors that are clearly external to the individual. By reordering employability in this way the framework restates that it is not just individual, supply-side factors that require detailed description and analysis, but all aspects of the employability equation, including demand.

\section{Conclusions}

This paper has analysed the concept of employability by discussing its importance to local, national and international labour market policy, considering working definitions of employability, tracing the historical 
development of the concept and examining how the concept is currently applied in UK labour market policy.

It is important to recognise that employability implicitly assumes specific types of demand that may vary across space, time and employers. Also, employers, potential employees and wider society can and do have fundamentally different perspectives on employability. Employability can be seen as referring to the individual's relationship with a single job (or 'class of jobs'), so that someone considered 'employable' for one job might not be considered so for a different job. From an employer's perspective, someone with appropriate employability skills and attributes may be 'employable', but this may be only the minimum criterion when considering candidates and no job offer may be made. From the job seeker's perspective, a lack of availability of enabling support (such as transport to work) or contract terms (such as the requirement for shift work) may mean that a specific job is not acceptable. From a policy-maker's perspective, the fact that the person does not take the job and remains unemployed suggests that (within the context of a specific vacancy or job role) the person is not 'employable'.

In recent years, many, but not all, researchers and policy-makers have used a 'narrow' concept of employability focusing upon 'employability skills and attributes', often resulting in purely supply-side 'employability' policies. This paper presents a 'broad' framework of employability, which takes account not only of 'individual factors' (including employability skills and attributes and job search), but also 'personal circumstances' and 'external factors'. Clearly, these factors have a close two-way interaction with each other.

Although the two perspectives are not mutually exclusive, there are at least two ways in which a 'broad' perspective can add to a 'narrow' concept of employability. First, the employability skills and attributes that an employer may demand depend upon the changing environment in which they operate, such as changing customer preferences, the actions of competitors and the state of the labour market. In a 'tight' labour market, an employer may accept (or find employable) someone whom they would not consider in a 'looser' labour market. Secondly, the 'narrow' view focusing on an individual's skills and attributes identifies important aspects of the employability equation, but omits other important aspects. For instance, there may be circumstances where job seekers with strong transferable skills and strategic job seeking will still struggle to find work - their actual 'employability' limited by-for example, family and caring responsibilities (which may also be a function of a lack of appropriate childcare provision and some employers' reluctance to develop family-friendly policies); problems in accessing transport and/or geographical remoteness; the numbers and/or type of vacancies within local labour markets; and the attitudes or recruiting methods of employers.

All of these factors should be incorporated within the concept of 'employability', if it relates to the ability of an (employed or unemployed) individual to move into or within employment rather than primarily to the minimum skills and attitudes that an employer requires of a job candidate.

A broad approach can help to move analysis and policy towards the identification of the full range of factors affecting a person's likelihood of getting a new job and so provide a framework for richer labour market models. It may also assist analysts and policy-makers to move towards more sustainable, long-term labour market strategies, by helping to identify the range of labour market factors that are, for example, stopping people moving into suitable work, the necessary interventions and their interconnections.

Furthermore, the long-term employability of job seekers and labour market programme participants is unlikely to be improved by training schemes that only consider employers' demands for competencies specific to their own immediate-term needs. Investment in skills that are genuinely transferable and of long-term value to employers, employees and other job seekers requires a substantial commitment to training within and beyond 
the workplace, and to the overcoming of the many other barriers to an individual's employability. Employers have a crucial role to play in the design and delivery of provisiondemand-responsive employability programmes and intermediate labour market projects have proved highly effective, both in offering training that is relevant and in providing participants with positive and sustainable outcomes. However, there remains a need for local and national policy-makers to ensure that the interests of all the key interest-groups-employers, job seekers and workers-are addressed and that the full range of barriers to work and progression is addressed in an integrated manner. Care needs to be taken to distinguish the many different causal implications of the many different elements contained in a 'broad' (or indeed a 'narrow') approach to employability.

Returning, finally, to the theoretical debate surrounding employability, there is a continuing need for researchers and policy analysts to investigate the full range of factors affecting the ability of individuals to attain 'the character or quality of being employable'. Employability used as a buzzword for welfare to work strategies adds little to our understanding of the existing debate on supply-side and demand-side explanations of labour market disadvantage. Employability deployed as a broad concept, enabling us to analyse and describe the multidimensional barriers to work or progression faced by many unemployed and employed people, offers an opportunity to transcend the orthodoxies of the supply-side versus demand-side debate, and arrive at explanations and policy solutions that reflect the multifaceted and complex combination of factors affecting the labour market interactions of those in and out of work.

\section{Note}

1. For instance, Gardner (1999) argues that there are eight forms of intelligence (i.e. the capacity to solve problems or to fashion products that are valued in one or more cultural setting) that are used concurrently and normally complement each other as an individual solves problems or develops a set of skills.
These are linguistic, logical-mathematical intelligence, musical intelligence, bodilykinesthetic (which may be of particular use for some physically demanding jobs), spatial, interpersonal (for example, working effectively with others), intrapersonal (the capacity to understand oneself, to appreciate one's feelings, fears and motivations) and naturalist intelligence (the ability to discriminate among living things as well as sensitivity to other features of the natural world).

\section{References}

AbBring, J., Berg, G. VAN DEN and Ours, J. VAN (2001) Business cycles and compositional variation in US unemployment, Journal of Business and Economic Statistics, 19, pp. 436-448.

ABERG, R. (2001) Equilibrium unemployment, search behaviour and unemployment persistency, Cambridge Journal of Economics, 25, pp. $131-147$.

AdAms, J., Greig, M. and McQuaid, R. W. (2000) Mismatch unemployment and local labour market efficiency: the role of employer and vacancy characteristics, Environment and Planning A, 32, pp. 1841-1856.

Adams, J., Greig, M. and McQuaid, R. W. (2002) Mismatch in local labour markets in central Scotland: the neglected role of demand, Urban Studies, 39(8), pp. 1399-1416.

Adam-Smith, D., Norris, G. and Williams, S. (2003) Continuity or change? The implications of the National Minimum Wage for work and employment in the hospitality industry, Work, Employment and Society, 17, pp. 29-47.

BARUCH, Y. (2001) Employability: a substitute for loyalty?, Human Resource Development International, 4, pp. 543-566.

BeCKer, G. (1975) Human Capital: A Theoretical and empirical Analysis, 2nd edn. New York: National Bureau for Economic Research.

Belt, V. and Richardson, R. (2005) Social labour, employability and social exclusion: pre-employment training for call centre work, Urban Studies, 42(2), pp. 257-270.

Blanchard, O. and Summers, L. (1987) Hysteresis in unemployment, European Economic Review, 31, pp. 288-295.

Bloeman, H. and Stancanelli, E. (2001) Individual wealth, reservation wages and transitions to employment, Journal of Labor Economics, 19, pp. 400-439.

Blunkett, D. (1999) Pessimistic pundits put on notice, The Guardian, 11 August, p. 25.

Boeri, T., LAyARD, R. and Nickell, S. (2000) Welfare to work and the fight against long-term unemployment. DfEE Research Report No. 206. Norwich: The Stationery Office. 
BoHeIM, R. and TAYLOR, M. P. (2001) Job search methods, intensity and success in Britain in the 1990s. Working Paper 01-07, Institute for Social and Economic Research, University of Essex, Colchester.

Brown, D. W. and Konrad, A. M. (2001) Jobseeking in a turbulent economy: social networks and the importance of cross-industry ties to industry change, Human Relations, 54(8), pp. 1015-1044.

BRyson, A. (2003) Permanent revolution: the case of Britain's welfare to work regime, Benefits, 11, pp. $11-17$.

Budd, A., Levine, P. and Smith, P. (1998) Unemployment, vacancies and the longterm unemployed, Economic Journal, 98, pp. 1071-1091.

CAMPBELl, M. (2000) Employability, adaptability and flexibility: changing labour market prospects, Regional Studies, 34, pp. 655-668.

Canadian labour Force Development Board (1994) Putting the pieces together: towards a coherent transition system for Canada's labour force. Ottawa: Canadian Labour Force Development Board.

CBI (CONFEDERATION OF BRITISH INDUSTRY) (1999) Making Employability Work: An Agenda for Action. London: CBI.

CEC (COMmission of THE European COMmuNITIES) (1999) The European Employment Strategy: Investing in People; Investing in More and Better Jobs. Luxembourg: Office for Official Publications of the European Communities.

CEC (2003a) Proposal for a council decision on guidelines for the employment policies of member states. Luxembourg: Office for Official Publications of the European Communities.

CEC (2003b) The Future of the European Employment Strategy: A Strategy for Full Employment and Better Jobs for All. Luxembourg: Office for Official Publications of the European Communities.

Chapple, K. (2002) Out of touch, out of bounds: how social networks shape the labour market radii of women on welfare in San Francisco, Urban Geography, 22, pp. 617-640.

Cook, J., Roche, M., Williams, C. C. and WindEBANK, J. (2001) The evolution of active welfare policies as a solution to social exclusion in Britain, Journal of European Area Studies, 9, pp. 13-26.

DAGUERRE, A. (2004) Importing workfare: policy transfer of social and labour market policies from the USA to Britain under New Labour, Social Policy and Administration, 38, pp. 41-56.

Dean, H., MacNeill, V. and Melrose, M. (2003) Ready to work? Understanding the experiences of people with multiple problems and needs, Benefits, 11, pp. 19-25.
DfEE (DePARTMENT FOR EDUCATION AND EMPlOyment) (1997a) DfEE Press Release 178/97: Blunkett's call to the nation to join his crusade for jobs. London: DfEE.

DfEE (1997b) The Design of the New Deal for 1824 Year Olds. London: DfEE.

DfEE (1997c) Learning and Working Together for the Future. London: DfEE.

DfEE (1998) The Design of the New Deal for Longterm Unemployed People. London: DfEE.

DfEE (2001) The UK Employment Action Plan. London: DfEE.

DHFETE (DePARTMENT OF Higher AND Further EDUCATION, TRAINING AND EMPLOYMENT) (2002) Report of the Taskforce on Employability and Long-term Unemployment. Belfast: DHFETE.

DrUCKer, P.F. (1985) Innovation and Entrepreneurship. London: Heinemann.

DSS (Department For Social Security) (1998) New Ambitions for Our Country: A New Contract for Welfare. London: DSS.

DWP (DePARTMENT FOR WORK AND PENSIONS) (2002) The UK Employment Action Plan 2002. London: DWP.

DWP (2003) Full Employment in Every Region. London: DWP.

ElLIG, B. R. (1998) Employment and employability: foundation of the new social contract, Human Resource Management, 37, pp. 173-175.

Etzoni, A. (1993) The Spirit of the Community. New York: Simon and Schuster.

Evans, C., Nathan, M. and Simmonds, D. (1999) Employability through Work. Manchester: Centre for Local Economic Strategies.

Evans, M. (2001) Britain: moving towards a work and opportunity-focused welfare state?, International Journal of Social Welfare, 10, pp. 260-266.

FinN, D. (2000) From full employment to full employability: a new deal for Britain's unemployed?, International Journal of Manpower, 21, pp. 384-399.

FinN, D. (2003) The 'employment-first' welfare state: lessons from the New Deal for Young People, Social Policy and Administration, 37, pp. 709-724.

FLETCHER, D. R. (2004) Demand-led programmes: challenging labour market inequalities or reinforcing them?, Environment and Planning $C$, 22, pp. $115-128$.

FreEMAN, R. (2000) The US 'underclass' in a booming economy, World Economics, 1, pp. 89-100.

GARDNER, H. (1999) Intelligence Reframed: Multiple Intelligences for the 21st Century. New York: Basic Books.

GAZIER, B. (1998a) Observations and recommendations, in: B. GAZIER (Ed.) Employability Concepts and Policies, pp. 298-315. Berlin: European Employment Observatory. 
GAZIER, B. (1998b) Employability - definitions and trends, in: B. GAZIER (Ed.) Employability: Concepts and Policies, pp. 37-71. Berlin: European Employment Observatory.

GAZIER, B. (2001) Employability: the complexity of a policy notion, in: P. WEINERT, M. Baukens, P. Bollerot et al. (Eds) Employability: From Theory to Practice, pp. 3-23. New Brunswick, NJ: Transaction Books.

GiBB, A. A. (1993) The enterprise culture and education, International Small Business Journal, 11 , pp. 11-34.

Glomb, T. M. and Tews, M. J. (2004) Emotional labor: a conceptualization and scale development, Journal of Vocational Behavior, 64, pp. $1-23$.

Granovetter, M. (1974) Getting a Job: A Study of Contacts and Careers. Cambridge, MA: Harvard University Press.

GrANOVETTER, M. (1982) The strength of weak ties: a network theory revisited, in: P. V. MARSDEN and N. Lin (Eds) Social Structure and Network Analysis, pp. 105-130. London: Sage.

GregG, P. and Wandsworth, J. (1996) How effective are state employment agencies? Jobcentre use and job matching in Britain, Oxford Review of Economics and Statistics, 58, pp. 443-467.

HARTSHORn, C. and SeAR, L. (2005) Employability and enterprise: evidence from the North East, Urban Studies, 42(2), pp. 271-283.

Haughton, G., Jones, M., Peck, J. et al. (2000) Labour market policy as flexible workfare: Prototype Employment Zones and the new workfarism, Regional Studies, 34, pp. 669-680.

HeEnAN, D. (2002) 'It won't change the world but it turned my life around': participants' views on the personal advisor scheme in the New Deal for Disabled People, Disability and Society, 17, pp. 383-401.

Hillage, J. and Pollard, E. (1998) Employability: Developing a Framework for Policy Analysis. London: DfEE.

HM TREASURY (1997) Treasury Press Release 122/97, 13th October: Gordon Brown unveils UK Employment Action Plan. London: HM Treasury.

Hofferth, S. L. and Iceland, J. (1998) Social capital in rural and urban communities, Rural Sociology, 63, pp. 574-598.

Holmes, L. M. (2001) Reconsidering graduate employability: the graduate identity approach, Quality in Higher Education, 7, pp. $111-119$.

Holzer, H. J. (1988) Search methods used by unemployed youths, Journal of Labor Economics, 6, pp. 1-20.
ILO (INTERNATIONAL LABOUR ORGANISATION) (2000) Training for Employment: Social Inclusion, Productivity Report $V$. Geneva: ILO.

Kleinman, M. and West, A. (1998) Employability and the New Deals, New Economy, 5, pp. $174-179$.

Kleinman, M., West, A. and Sparkes, J. (1998) Investing in employability: the roles of business and government in the transition to work. London: London School of Economics.

LABOUR PARTy (2001) Ambitions for Britain: Labour's Manifesto. London: Labour Party.

LAKey, J., BARnes, H. and PARry, J. (2001) Getting a Chance: Employment Support for Young People with Multiple Disadvantages. York: Joseph Rowntree Foundation.

LAYARD, R. (1997) Preventing long-term unemployment: an economic analysis, in: D. J. SNOWER and G. DE LA DeHESA (Eds) Unemployment Policy: Government Options for the Labour Market, pp. 333-348. Cambridge: Cambridge University Press.

LAYARD, R. (2000) Welfare-to-work and the New Deal, World Economics, 1, pp. 29-39.

LAYARD, R., NickelL, S. and JACKMAN, R. (1991) Unemployment, Macroeconomic Performance and the Labour Market. Oxford: Oxford University Press.

LAYARD, R., Nickell, S. and JACKMAN, R. (1994) The Unemployment Crises. Oxford: Oxford University Press.

LeDrut, R. (1966) Sociologie du chômage. Paris: PUF.

LÉvesque, M. and White, D. (2001) Capital social, capital humain et sortie de l'aide sociale pour des prestataires de longue durée, Canadian Journal of Sociology, 26, pp. 167-192.

Lindsay, C. (2001) A new deal through partnership, a new approach to employability: the New Deal for Young People in the United Kingdom, in: A. Serrano Pascual (Ed.) The Role of Social and Civil Partnerships in Combating Youth Unemployment, pp. 173-190. Brussels: European Trade Union Institute.

LinDSAY, C. (2002) Long-term unemployment and the employability gap: priorities for renewing Britain's New Deal, Journal of European Industrial Training, 26, pp. 411-419.

LindsAy, C. and MCQUAID, R. W. (2004) Avoiding the 'McJobs': unemployed job seekers and attitudes to service work, Work, Employment and Society, 18, pp. 297-318.

LindSAy, C., McCRACKEN, M. and McQuaId, R. W. (2003) Unemployment duration and employability in remote rural labour markets, Journal of Rural Studies, 19, pp. 187-200. 
LISTER, R. (2001) Work for those who can, security for those who cannot: a Third Way in social security reform or fractured social citizenship? in: R. EDWARDS and J. Glover (Eds) Risk and Citizenship: Key Issues in Welfare, pp. 96115. London: Routledge.

Machin, S. and Manning, A. (1999) The causes and consequences of long-term unemployment in Europe, in: O. Ashenfelter and D. CARD (Eds) Handbook of Labor Economics, pp. 3085-3139. Amsterdam: Elsevier.

Martin, R. L., Morrison, P. and Nativel, C. (2003) The local impact of the New Deal: does geography matter?, in: R. L. MARTIN and P. MORRISON (Eds) Local Labour Markets: Processes, Problems and Policies, pp. 175-207. London: Routledge.

Mclaughlin, E., Trewsdale, J. and Mccay, N. (2001) The rise and fall of the UK's first tax credit: the Working Families Tax Credit 1998-2000, Social Policy and Administration, 35, pp. $163-180$.

MCQUAID, R. W. (2002) Entrepreneurship and ICT industries: support from regional and local policies, Regional Studies, 36, pp. 909-919.

McQuaid, R. W. and Lindsay, C. (2002) The 'employability gap': long-term unemployment and barriers to work in buoyant labour markets, Environment and Planning C, 20, pp. 613-628.

McQuaid, R. W., Greig, M., and Adams, J. (2004) Are New Deal employment initiatives on target? Evidence from job search success in local labour markets, International Journal of Manpower, 22, pp. 392-410.

McQuaid, R. W., Lindsay, C. and GReig, M. (2003) Wired for work? ICT and job seeking in rural areas. A Report For The Joseph Rowntree Foundation. York: York Publishing.

Millar, J. (2000) Keeping Track of Welfare Reform: The New Deal Programmes. York: Joseph Rowntree Foundation.

Monk, S., Dunn, J., Fitzgerald, M. and Hodge, I. (1999) Finding Work in Rural Areas: Barriers and Bridges. York: Joseph Rowntree Foundation.

Murray, C. (1990) The Emerging British Underclass. London: IEA.

NiCKELL, S. (1998) Unemployment: questions and some answers, Economic Journal, 108, pp. 802-816.

Nickell, S. and Quintini, G. (2002) The recent performance of the UK labour market, Oxford Review of Economic Policy, 18, pp. 202-220.

Nickson, D., Warhurst, C., Cullen, A. and WATt, A. (2003) Bringing in the excluded? Aesthetic labour, skills and training in the 'new' economy, Journal of Education and Work, 16, pp. 185-203.

OECD (ORgANISATION FOR ECONOMIC COOPERATION AND DEVElOPMENT) (1994a) The
OECD Jobs Study: Evidence and Explanations. Paris: OECD.

OECD (1994b) New Orientations for Social Policy. Paris: OECD.

OECD (1998) Human Capital Investment: An International Comparison. Paris: OECD.

OsberG, L. (1993) Fishing in different pools: job search strategies and job finding success in Canada in the early 1980s, Journal of Labor Economics, 11, pp. 348-386.

PeCK, J. (2001) Workfare States. New York: Guilford.

Peck, J. and Theodore, N. (2000) Beyond employability, Cambridge Journal of Economics, 24, pp. 729-749.

PhilpotT, J. (1998) Improving employability and welfare to work policies: a UK perspective, in: B. Gazier (Ed.) Employability: Concepts and Policies, pp. 97-120. Berlin: European Employment Observatory.

Philpott, J. (1999) Behind the 'Buzzword': Employability. London: Employment Policy Institute.

Powell, M. (2000) New Labour and the Third Way in the British welfare state: a new and distinctive approach?, Critical Social Policy, 20, pp. 39-60.

RAJAN, A. (1997) Employability in the finance sector: rhetoric vs. reality, Human Resource Management Journal, 7, pp. 67-78.

Robson, M. T. (2001) Regional variations in the competitiveness of unemployed job seekers and the rate of outflow from unemployment. Oxford Bulletin of Economics and Statistics, 63, pp. 61-90.

Roulstone, A. (2000) Disability, dependency and the New Deal for Disabled People, Disability and Society, 15, pp. 427-444.

Saint-Paul, G. (1996) Are the unemployed unemployable?, European Economic Review, 40, pp. 1501-1519.

Serrano Pascual, A. (2001a) The European Employment Strategy to tackle youth unemployment: the concept of employability. Paper presented at the European Industrial Relations Congress, Oslo, June.

Serrano Pascual, A. (2001b) The role of social and civil partnership networks in combating youth unemployment: bridging the gap between the European and the local level, in: A. Serrano Pascual (Ed.) The Role of Social and Civil Partnerships in Combating Youth Unemployment, pp. 13-59. Brussels: European Trade Union Institute.

SinfiEld, A. (2001) Benefits and research in the labour market, European Journal of Social Security, 3, pp. 209-235.

Stoloff, J. A., Glanville, J. L. and BienENSTOCK, E. J. (1999) Women's partici- 
pation in the labor force: the role of social networks, Social Networks, 21, pp. 91-108.

Thomas, J. (1997) Public employment agencies and unemployment spells: reconciling the experimental and nonexperimental evidence, Industrial and Labor Relations Review, 50, pp. 667-685.

Turok, I. and Edge, N. (1999) The Jobs Gap in Britain's Cities: Employment Loss and Labour Market Consequences. Bristol: Policy Press.

UN (United Nations) (2001) Recommendations of the High Level Panel of the Youth Employment Network. New York: United Nations.

VerhaAR, C. H. A. and Smulders, H. R. M. (1999) Employability in practice, Journal of European Industrial Training, 23, pp. 268-274.
Wanberg, C., Kanfer, R. and Rotundo, M. (1999) Unemployed individuals: motives, job search competencies, and job search constraints as predictors of job seeking and re-employment, Journal of Applied Psychology, 84, pp. 987-910.

Webster, D. (2000) The geographical concentration of labour market disadvantage, Oxford Review of Economic Policy, 16, pp. 114-128.

White, M. (2000) The New Deal for Young People: towards an ethical employment policy?, Policy Studies, 21, pp. 285-299.

Witz, A., WARHurst, C. and NiCKSON, D. (2003) The labour of aesthetics and the aesthetics of organisation, Organisation, 10, pp. 33-54. 
